\title{
Characterization and Structural Prediction of ORF10, ORF7b, ORF7a, ORF6, Membrane Glycoprotein, and Envelope Protein in SARS-CoV-2 Bangladeshi Variant through Bioinformatics Approach
}

Pinky Debnath $\left(1^{\text {st }}\right.$ author $)$

Research Assistant,

Chemical Biotechnology Department, Technical University of Munich,

Schuigasse 22, D-94315 Straubing, Germany.

E-mail: ge28pes@mytum.de

Contact: +8801771183801

Umama Khan ( $2^{\text {nd }}$ author)

Research Assistant,

Biotechnology and Genetic Engineering Discipline, Khulna University,

Khulna-9208, Bangladesh.

E-mail: ms180744@bge.ku.ac.bd

ORCID: 0000-0002-6823-8352

Contact: +8801315867546

Md. Salauddin Khan ( $3^{\text {rd }}$ author \& Correspondence)

Assistant Professor,

Statistics Discipline, Khulna University, Khulna-9208, Bangladesh.

ORCID: 0000-0002-5001-7877

E-mail: salauddinstat@ku.ac.bd

Contact: +8801737220964 


\begin{abstract}
The acute respiratory disease induced by the severe acute respiratory syndrome-coronavirus-2 (SARS$\mathrm{CoV}-2$ ) has become a global epidemic in just less than a year by the first half of 2020. The subsequent efficient human-to-human transmission of this virus eventually affected millions of people worldwide. The most devastating thing is that the infection rate is continuously uprising and resulting in significant mortality especially among the older age population and those with health co-morbidities. This enveloped, positive-sense RNA virus is chiefly responsible for the infection of the upper respiratory system. The virulence of the SARS-CoV-2 is mostly regulated by its proteins like entry to the host cell through fusion mechanism, fusion of infected cells with neighboring uninfected cells to spread the virus, inhibition of host gene expression, cellular differentiation, apoptosis, mitochondrial biogenesis, etc. But very little is known about the protein structures and functionalities. Therefore, the main purpose of this study is to learn more about these proteins through bioinformatics approaches. In this study, ORF10, ORF7b, ORF7a, ORF6, membrane glycoprotein, and envelope protein have been selected from a Bangladeshi Corona-virus strain G039392 and a number of bioinformatics tools (MEGA-X-V10.1.7, PONDR®, ProtScale, ProtParam, SCRIBER, NetSurfP v2.0, IntFOLD, UCSF Chimera, and PyMol) and strategies were implemented for multiple sequence alignment and phylogeny analysis with 9 different variants, predicting hydropathicity, amino acid compositions, protein-binding propensity, protein disorders, 2D and 3D protein modeling. Selected proteins were characterized as highly flexible, structurally and electrostatically extremely stable, ordered, biologically active, hydrophobic, and closely related to the proteins of different variants. This detailed information regarding the characterization and structure of proteins of SARS-CoV-2 Bangladeshi variant was performed for the first time ever to unveil the deep mechanism behind the virulence features and also, this robust appraisal paves the future way for molecular docking, vaccine development targeting these characterized proteins.
\end{abstract}

Keywords: SARS-CoV-2, ORF proteins, Membrane and Envelope protein, Bangladeshi Covid-19 variant, Structural prediction, Bioinformatics. 


\section{Introduction}

In December 2019, the whole world was stunned by the outbreak of unknown cause pneumonia, which was originated from Wuhan, Hubei province of China. And then, by Jan 7, 2020, Chinese scientists have screened a novel Coronavirus (CoV) mainly responsible for the infection of the upper respiratory system from patients in Wuhan [1]. The ensuing proficient human-to-human transmission of the virus ultimately affected millions of people worldwide. Since July 2021, there were 183 million confirmed cases and 3.97 million people have died around the world by this devastating virus. The most devastating thing is that the infection rate is continuously uprising which is resulting in significant mortality especially among the older age population and those with health co-morbidities.

Coronaviruses are very tiny in size (diameter, 65-125 nm) consist of a single-strand RNA as nucleic material [2,3]. Along with RNA, this particular virus consists of 12 different proteins such as nonstructural proteins (ORF1a and ORF1b) at the 5'-end, structural proteins (spike surface glycoprotein $(\mathrm{S})$, envelope $(\mathrm{E})$, matrix $(\mathrm{M})$, and nucleocapsid $(\mathrm{N})$ ) and multiple lineage-specific accessory proteins (ORF3a, ORF6, ORF7b, ORF8, and ORF10) at the 3'-end [4]. Although these proteins are basically involved in host receptor recognition, attachment, and entry into host cells, very slight is recognized about these protein structures and specific functionalities. The ORF10 protein is found upstream of the 3'-untranslated region (3'-UTR), apparently encodes for a protein of 38 amino acids long [5]. The ORF7b protein is a presumed viral accessory protein encoded on subgenomic (sg) RNA 7 [6], whereas, ORF7a possessed a distinctive immunoglobulin (Ig)-like domain with a 15-a.a single peptide sequence at its $\mathrm{N}$ terminus, an 81-a.a luminal domain, a 21 a.a transmembrane domain, and a short C-terminal tail [7]. Also, the SARS-CoV ORF6 is characteristically between 42 to 63 amino acids in length and by transcribing into mRNA6 encodes SARS 6 protein [8]. Moreover, the membrane glycoprotein is found abundantly and plays the main role in virion assemble, morphogenesis, and, also, define the shape of the viral envelope $[9,10]$. Lastly, the envelope proteins are short-chain polypeptide with a single $\alpha$ helical transmembrane domain that can produce homopentametric ion channels (IC) [11].

Though Bangladesh is not exempt from the severe outbreak of the Coronavirus, a large number of Bangladeshi strains also have been identified. On 8 March 2020, in Bangladesh, SARS-CoV-2 was reported for the very first time. A new strain was acknowledged on January 2021, from a 50-year-old symptomatic male patient in Dhaka, Bangladesh (SARS-CoV-2 strain G039392) and the strain was found as $99.9 \%$ identical to the UK variant B.1.1.7 [12]. In this study, six proteins (ORF10, ORF7b, ORF7a, ORF6, membrane glycoprotein, and envelope protein) were randomly selected from the 
SARS-CoV-2 Bangladeshi strain G039392 regarding characterization, so that more detailed studies could elucidate their structures and provide insights into the possible functions for the selected proteins. Therefore, the major purpose of this analysis is to learn more about these proteins like the assessment of a.a composition, the energy level of chemical bonds, hydropathicity, etc. through bioinformatics approaches which could provide insight into probing novel functions regarding virulence of Covid-19. Moreover, structural prediction of 2D and 3D SARS-CoV-2 protein models could give further way to docking molecular components which can optimize devastating viral properties of this particular virus. Thereby, this study utilizes strictly bioinformatics approaches to theoretically characterize, classify, and construct the putative structure of selected 6 proteins in SARS-CoV-2 Bangladeshi strain G039392.

\section{Materials and Method}

\subsection{Sequence Alignment and Phylogenetic Analysis}

The reference sequence corresponding to the selected six proteins (ORF10, ORF7b, ORF7a, ORF6, membrane glycoprotein, and envelope protein) in SARS-CoV-2 strain G039392, along with other 9 variants from 9 different countries, were acquired from NCBI's Protein Database. Sequences were aligned using MUSCLE on the MEGA-X-V10.1.7 software [13,14]. The neighbor-joining method was implemented by maintaining other default settings. Alignments reliability was measured by overall mean distance ( $\leq 0.7$ is reliable) and determined using p-distance substitution model [15]. The protein trees were constructed using the neighbor-joining method and visualized on MEGA-X-V10.1.7. The phylogeny trees were tested using the bootstrap method.

\subsection{Protein Characterization}

Phosphorylation sites were detected by DEPP server of PONDR® [16]. ProtScale was used to generate hydrophobicity plot and ProtParam to determine the grand average of hydrophobicity (GRAVY) $[17,18]$. Also, the protein disorder predictions were performed using PONDR® (Predictor of Natural Disordered Regions) VLS2, XL1 [19]. Moreover, amino acid compositions and aliphatic index were analyzed employing ProtParam. Finally, the protein-binding propensities of the interacting residues were evaluated using SCRIBER [20].

\subsection{Protein Secondary Structure Prediction, 3D Modeling, Evolution and Validation}

NetSurfP v2.0 server was employed to predict the protein secondary structure [21]. The predictions of transmembrane helix (TH) were performed by TMHMM [22] and Phobius [23] by averaging the predictions and the most constant range of scores were utilized for analysis. The web server IntFOLD was used to make use of an ab initio modeling for constructing the selected proteins [24]. According to 
the IntFOLD's quality and confidence scoring, the models were evaluated and utilizing the 3Drefine web-server, the best model was then refined [25]. The maximum QMEAN Z-score [26] and Ramachandran plot [27] were considered as most favorable among the five generated post-refinement models. Both UCSF Chimera and PyMol were used to visualize the most favorable 3D protein model $[28,29]$. The hydrophobicity surfaces were created according to the Kyte-Doolittle scale [30].

\section{Results}

\subsection{Sequence Alignment and Phylogenetic Analysis}

In phylogenetic tree, the overall mean distance of ORF10 is 0.01 , which is corresponding to almost 99.9\% identity for the entire alignment (Figure 1G). The ORF10 protein from the strain of Spain has shown difference at the $30^{\text {th }}$ position which is Leu (L) rather than Val (V) (Figure 1A). So, the height of the conserved region is from 1 to 29 residues. While, for ORF7b, ORF7a and ORF6, membrane glycoprotein, envelope protein, the mean distance is 0.00 along with $100 \%$ conserved regions which are correspondences for the entire alignment (Figure 1).

A Species/Abbrv

2. QTH36450.1 ORF10 protein India

3. QQH15831.1 ORF10 protein Pakistan

5. QSJ03242.1 ORF10 protein China

6. QQX99448.1 ORF10 protein Bangladesh

7. QNC68227.1 ORF10 protein United Kingdom

8. QRN56067.1 ORF10 protein Brazil

9. QUQ05565.1 ORF10 protein Spain

10. QTH25072.1 ORF10 protein Germany
1. QUR41323.1 ORF10 protein Egypt

4. QUS53241.1 ORF10 protein USA: Ohio

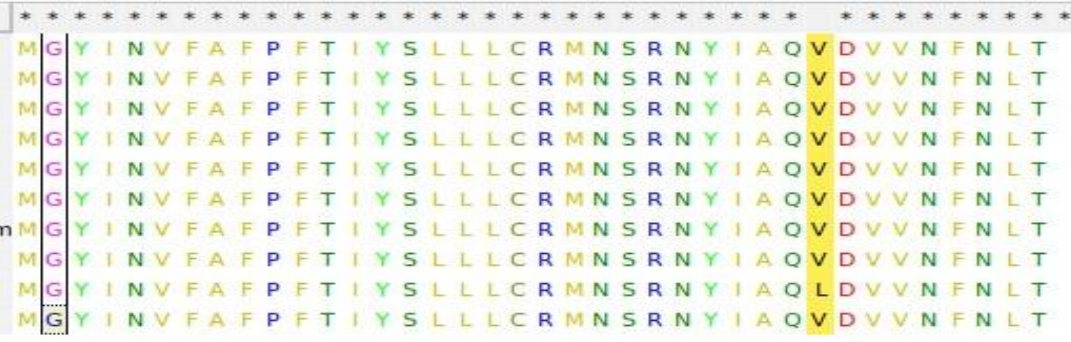

Species/Abbrv

B 1.QPZ33369.1 ORF7b protein Germany 2. QTH36387.1 ORF7b protein India 3. QQH15720.1 ORF7b protein Pakistan 4. QMT27596.1 ORF7b protein Brazil 5. QNC68224.1 ORF7b protein United Kingdom 6. QTZ81998.1 ORF7b protein Spain 7. QJF74861.1 ORF7b protein China 8. QUS53226.1 ORF7b protein USA: Ohio 9. QQX99445.1 ORF7b protein Bangladesh 10. QUR41332.1 ORF7b protein Egypt

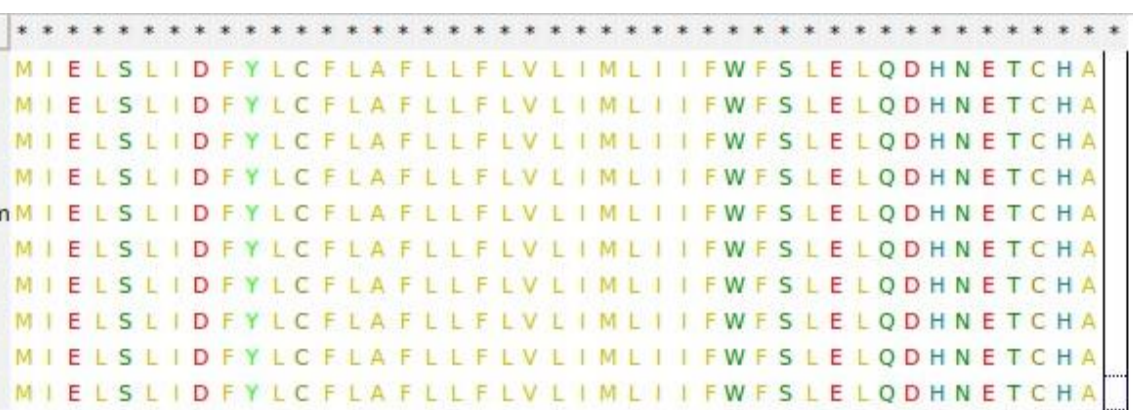


bioRxiv preprint doi: https://doi.org/10.1101/2021.10.01.452232; this version posted October 4, 2021. The copyright holder for this preprint (which was not certified by peer review) is the author/funder. All rights reserved. No reuse allowed without permission.

C

Species/Abbrv

1. QRW41651.1 ORF7a protein Germany 2. QUS53201.1 ORF7a protein USA: Ohio 3. QTH36434.1 ORF7a protein India 4. QQH15755.1 ORF7a protein Pakistan 5. QJF74848.1 ORF7a protein China 6. Q0D07314.1 ORF7a protein United Kingdom 7. QMT29014.1 ORF7a protein Brazil 8. QUR41390.1 ORF7a protein Egypt 9. QQX99444.1 ORF7a protein Bangladesh 10. QUQ05561.1 ORF7a protein Spain $* * * * * * * * * * * * * * * * * * * * * * * * * * * * * * * * * * * * * * * * * * * * * * * * * * * * * * * * * * * * * * * * * * * * * * * * * * * * * *$ |KI ILFLALITLATCELYHYQECVRGTTVLLKEPCSSGTYEGNSPFHPLADNKFALTCFSTQFAFACPDGVKHVYQLR KIILFLALITLATCELYHYQECVRGTTVLLKEPCSSGTYEGNSPFHPLADNKFALTCFSTQFAFACPDGVKHVYQLR KIILFLALITLATCELYHYQECVRGTTVLLKEPCSSGTYEGNSPFHPLADNKFALTCFSTQFAFACPDGVKHVYQLR KI I LFLALITLATCELYHYQECVRGTTVLLKEPCSSGTYEGNSPFHPLADNKFALTCFSTQFAFACPDGVKHVYQLR KIILFLALITLATCELYHYQECVRGTTVLLKEPCSSGTYEGNSPFHPLADNKFALTCFSTQFAFACPDGVKHVYQLR KI ILFLALITLATCELYHYQECVRGTTVLLKEPCSSGTYEGNSPFHPLADNKFALTCFSTQFAFACPDGVKHVYQLR KIILFLALITLATCELYHYQECVRGTTVLLKEPCSSGTYEGNSPFHPLADNKFALTCFSTQFAFACPDGVKHVYQLR KI ILFLALITLATCELYHYQECVRGTTVLLKEPCSSGTYEGNSPFHPLADNKFALTCFSTQFAFACPDGVKHVYQLR WKIILFLALITLATCELYHYQECVRGTTVLLKEPCSSGTYEGNSPFHPLADNKFALTCFSTQFAFACPDGVKHVYQLR MKIILFLALITLATCELYHYQECVRGTTVLLKEPCSSGTYEGNSPFHPLADNKFALTCFSTQFAFACPDGVKHVYQLR.

D

Species/Abbrv

1. QUS53212.1 ORF6 protein USA: Ohio

2. QMT97865.1 ORF6 protein Brazil

3. QQH15706.1 ORF6 protein Pakistan

4. QTH36373.1 ORF6 protein India

5. QTC10206.1 ORF6 protein Spain

6. QNC68222.1 ORF6 protein United Kingdom

7. QUR41413.1 ORF6 protein Egypt

8. QTH25067.1 ORF6 protein Germany

9. QQX99443.1 ORF6 protein Bangladesh

10. QNT09980.1 ORF6 protein China

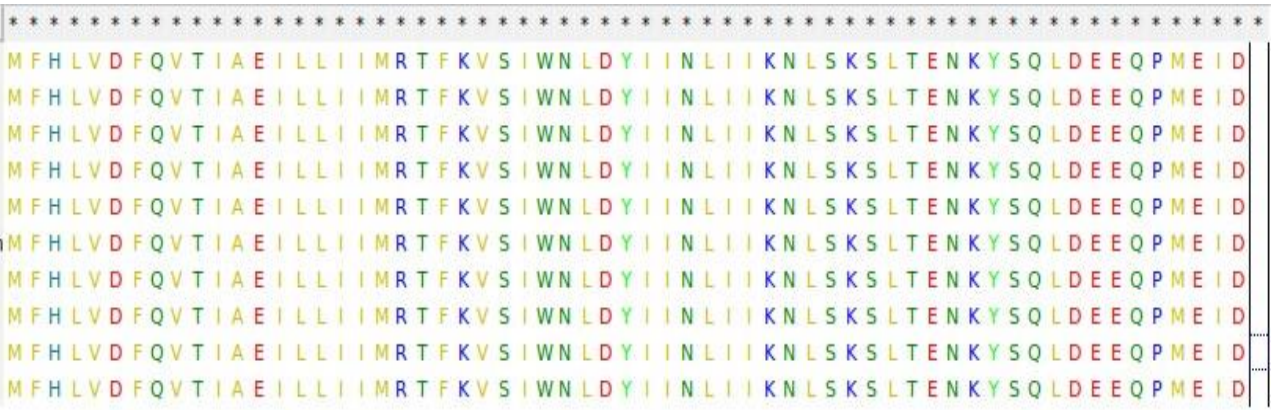

$\mathbf{E}$

Species/Abbrv

$* * * * * * * * * * * * * * * * * * * * * * * * * * * * * * * * * * * * * * * * * * * * * * * * * * * * * * * * * * * * * * * * * * * * * * * * * *$

1. QUR41412.1 membrane glycoprotein Egypt

MADSNGT | TVEELKKLLEQWNLVIGFLFLTWICLLQFAYANRNRFLY|IKLIFLWLLWPVTLACFVLAAVYR |N

2. QUS53223.1 membrane glycoprotein USA:Ohio

MADSNGTITVEELKKLLEQWNLVIGFLFLTWICLLQFAYANRNRFLYI|KLIFLWLLWPVTLACFVLAAVYR |N

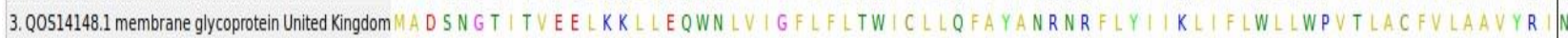

4. QTH36408.1 membrane glycoprotein India

MADSNGTITVEELKKLLEQWNLVIGFLFLTWICLLQFAYANRNRFLYIIKLIFLWLLWPVTLACFVLAAVYR IN

5. QQH15777.1 membrane glycoprotein Pakistan

6. QMT27593.1 membrane glycoprotein Brazil

7. QPZ33366.1 membrane glycoprotein Germany

MADSNGTITVEELKKLLEQWNLVIGFLFLTWICLLQFAYANRNRFLYIIKLIFLWLLWPVTLACFVLAAVYRIN

MADSNGTI TVEELKKLLEQWNLVIGFLFLTWICLLQFAYANRNRFLYIIKLIFLWLLWPVTLACFVLAAVYRIN

10. QUQ05559.1 membrane glycoprotein Spain

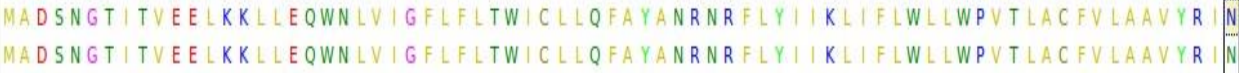

MADSNGT I TVEELKKLLEQWNLVIGFLFLTWICLLQFAYANRNRFLYIIKLIFLWLLWPVTLACFVLAAVYR|N|

F

Species/Abbry

$* * * * * * * * * * * * * * * * * * * * * * * * * * * * * * * * * * * * * * * * * * * * * * * * * * * * * * * * * * * * * * * * * * * * * * * * * * * *$

1. QRW41660.1 envelope protein Germany

2. QQH15752.1 envelope protein Pakistan

3. QSJ03265.1 envelope protein China

4. QTC10216.1 envelope protein Spain

MYSFVSEETGTLIVNSVLLFLAFVVFLLVTLAILTALRLCAYCCNIVNVSLVKPSFYVYSRVKN LNSSRVPDL

MYSFVSEETGTLIVNSVLLFLAFVVFLLVTLAILTALRLCAYCCNIVNVSLVKPSFYVYSRVKNLNSSRVPDLLV

MYSFVSEETGTLIVNSVLLFLAFVVFLLVTLAILTALRLCAYCCNIVNVSLVKPSFYVYSRVKNLNSSRVPDLLV

MYSFVSEETGTLIVNSVLLFLAFVVFLLVTLAILTALRLCAYCCNIVNVSLVKPSFYVYSRVKNLNSSRVPDLLV

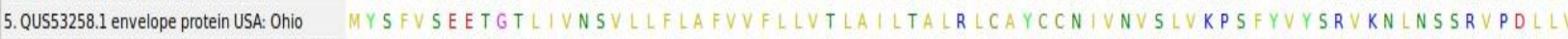

6. QNC68220.1 envelope protein United Kingdom M Y S FV SEETGTLIVNSVLLFLAFVVFLLVTLAILTALRLCA YCCNIVNVSLVKPSFYVYSRVKN LNSSRVPDLLV

7. QUR41328.1 envelope protein Egypt MYSFVSEETGTLIVNSVLLFLAFVVFLLVTLAILTALRLCAYCCNIVNVSLVKPSFYVYSRVKNLNSSRVPDLLV

8. QMT97875.1 envelope protein Brazil MYSFVSEETGTLIVNSVLLFLAFVVFLLVTLAILTALRLCAYCCNIVNVSLVKPSFYVYSRVKNLNSSRVPDLLV

9. QQX99441.1 envelope protein Bangladesh MYS FVSEETGTLIVNSVLLFLAFVVFLLVTLAILTALRLCAYCCNIVNVSLVKPSFYVYSRVKNLNSSRVPDLLV

10. QTH36371.1 envelope protein India

MYSFVSEETGTLIVNSVLLFLAFVVFLLVTLAILTALRLCAYCCNIVNVSLVKPSFYVYSRVKNLNSSRVPDLLVI 
G

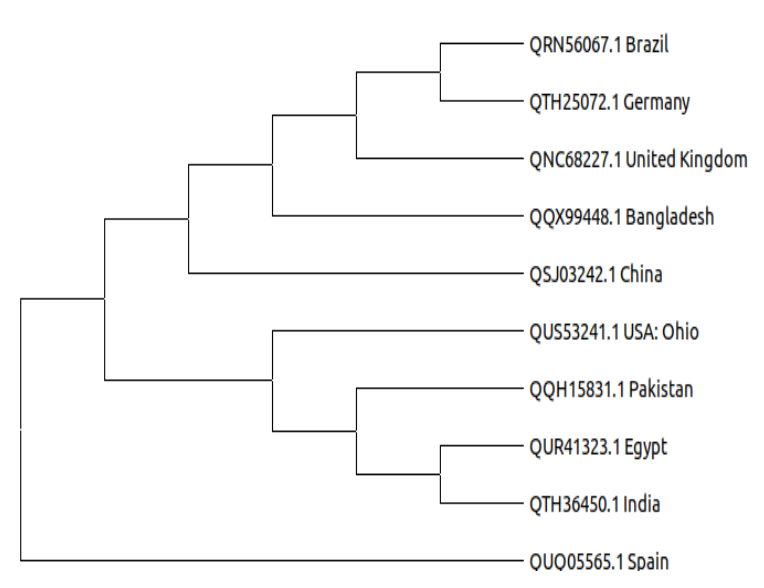

I

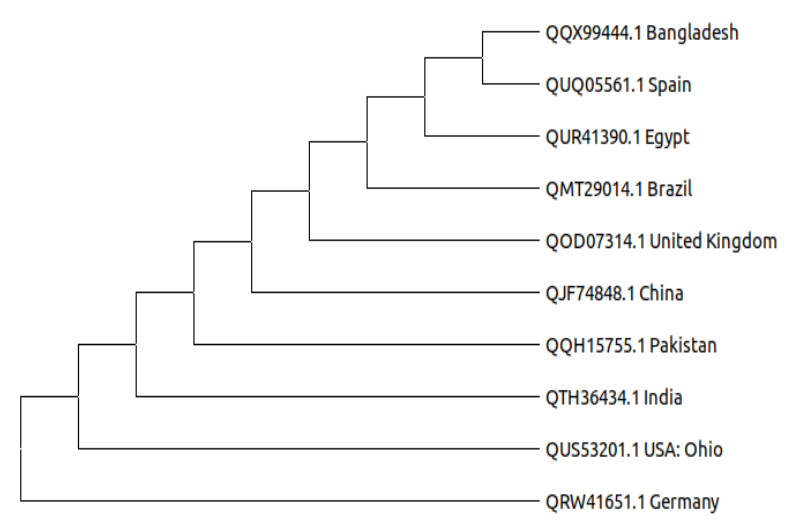

K

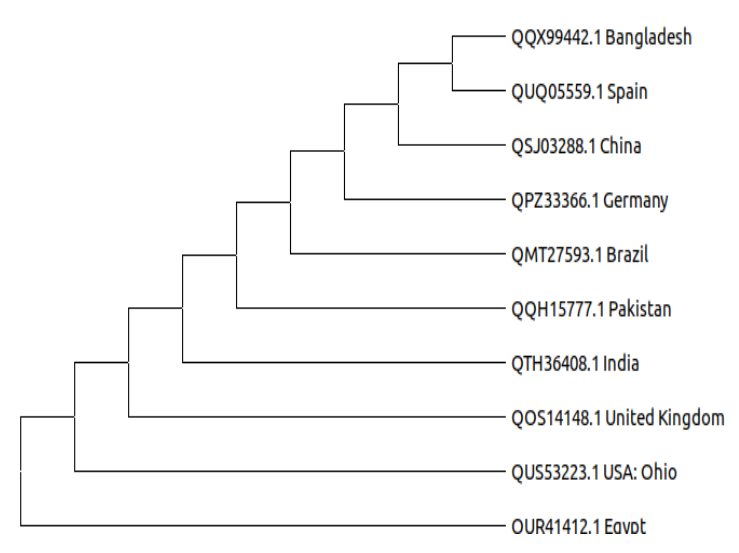

H

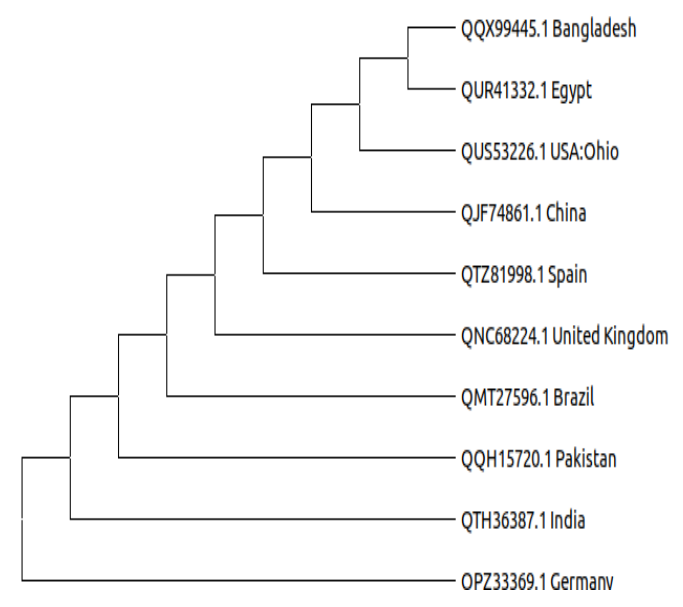

J

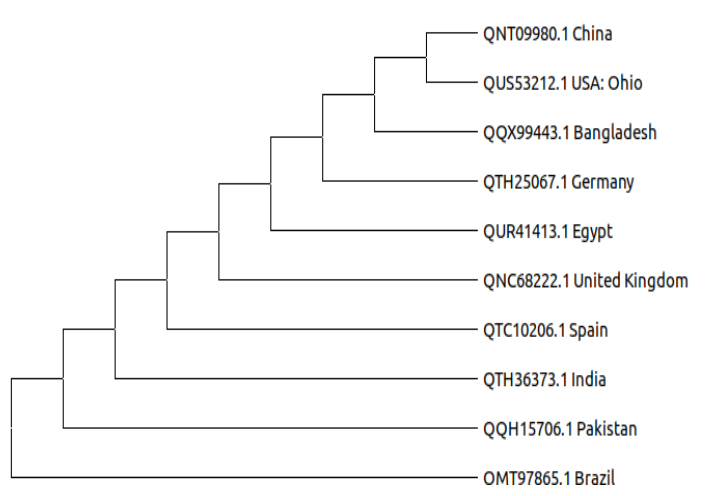

L

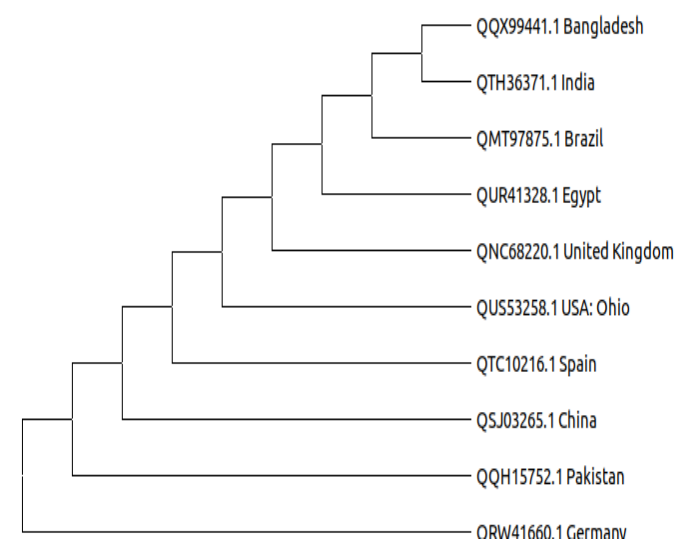

Figure 1. Multiple sequence alignment and Phylogenetic analysis of six different protein sequences depicting evolutionary relationships with SARS-CoV-2 varieties of 10 different Countries. 1A-F. Sequence alignment of ORF10, ORF7b, ORF7a and ORF6, membrane glycoprotein, and envelope protein respectively. 1G-L. Neighbor joining phylogenetic tree of ORF10, ORF7b, ORF7a and ORF6, 
membrane glycoprotein, and envelope protein respectively. All proteins appear closely related to the proteins of different variants of different countries.

\subsection{Phosphorylation}

Single phosphorylation site (phosphorylated serine) was identified in ORF7a consist of 14.29\%, whereas other proteins did not show any Phosphorylation sites (Table 1).

Table 1. Phosphorylation sites of the selected proteins.

\begin{tabular}{|l|l|l|l|}
\hline Protein Name & $\begin{array}{l}\text { Number of } \\
\text { Phosphorylated } \\
\text { Serines }\end{array}$ & $\begin{array}{l}\text { Number of } \\
\text { Phosphorylated } \\
\text { Threonines }\end{array}$ & $\begin{array}{l}\text { Number of } \\
\text { Phosphorylated } \\
\text { Tyrosines }\end{array}$ \\
\hline ORF10 Protein & 0 out of $2(0.00 \%)$ & o out of $2(0.00 \%)$ & o out of $3(0.00 \%)$ \\
\hline ORF7b Protein & 0 out of $2(0.00 \%)$ & 0 out of $1(0.00 \%)$ & 0 out of $1(0.00 \%)$ \\
\hline ORF7a Protein & 1 out of $7(14.29 \%)$ & 0 out of $10(0.00 \%)$ & 0 out of $5(0.00 \%)$ \\
\hline ORF6 Protein & 0 out of $4(0.00 \%)$ & 0 out of $3(0.00 \%)$ & 0 out of $2(0.00 \%)$ \\
\hline $\begin{array}{l}\text { Membrane } \\
\text { Glycoprotein }\end{array}$ & 0 out of $15(0.00 \%)$ & 0 out of $13(0.00 \%)$ & 0 out of $9(0.00 \%)$ \\
\hline Envelope Protein & 0 out of $8(0.00 \%)$ & 0 out of $4(0.00 \%)$ & 0 out of $4(0.00 \%)$ \\
\hline
\end{tabular}

\subsection{Hydropathicity}

In ORF10 protein, the hydrophobicity plot exposed two hydrophobic regions spanning residues 3-20 and 28-35 along with two hydrophilic regions; residues 21-27 and a residue of 36 (Figure 2A). There are single hydrophilic and hydrophilic regions spanning residues 3-32 and 33-41, respectively in ORF7b protein (Figure 2B). In case of ORF7a protein, hydrophobic regions are 3-16, 25,28-31, 47-48, 54-61, 63-67, 69, 72, 84-88, 98-115 and the hydrophilic regions are 17-24, 26-27, 32-46, 49-53, 62,68, 70-71, 76-83, 89-97, 116-119 with the neutral regions 73, 75 (Figure. 2C). In ORF6 protein, the hydrophobic regions are 3-7, 9-20, 23-28, 31-39, 42, hydrophilic regions are 8, 21-22, 29, 40-41, 43-59 with a neutral position 30 (Figure 2D). Moreover, for membrane glycoprotein, 8-11, 15, 21-39, 46-71 ,74-75, 77-102, 104, 110, 117-122, 124, 126-132, 134, 137-146, 149-151, 168-171, 182-183, 189, 193 195, 217-220 are hydrophobic positions, while 3-7, 12-14, 16-20, 40-45, 72-73, 76, 103, 105-109, 111116, 123, 125, 133, 135-136, 147-148, 152-167, 173-180, 184-188, 190-192, 196-216 are hydrophilic position and neutral places are 172, 181(Figure 2E). Whereas, in case of envelop protein, hydrophobic region residues are 3-5, 11-54, 56-58,60, $72-73$ and hydrophilic region residues are 6-10, 55, 59, 6171(Figure 2F). The GRAVY scores are 0.64, 1.45, 0.32, 0.23, 0.45 and 1.13, respectively for ORF10, ORF7b, ORF7a, ORF6, membrane glycoprotein and envelope protein (Figure 2G). 
bioRxiv preprint doi: https://doi.org/10.1101/2021.10.01.452232; this version posted October 4, 2021. The copyright holder for this preprint (which was not certified by peer review) is the author/funder. All rights reserved. No reuse allowed without permission.

A

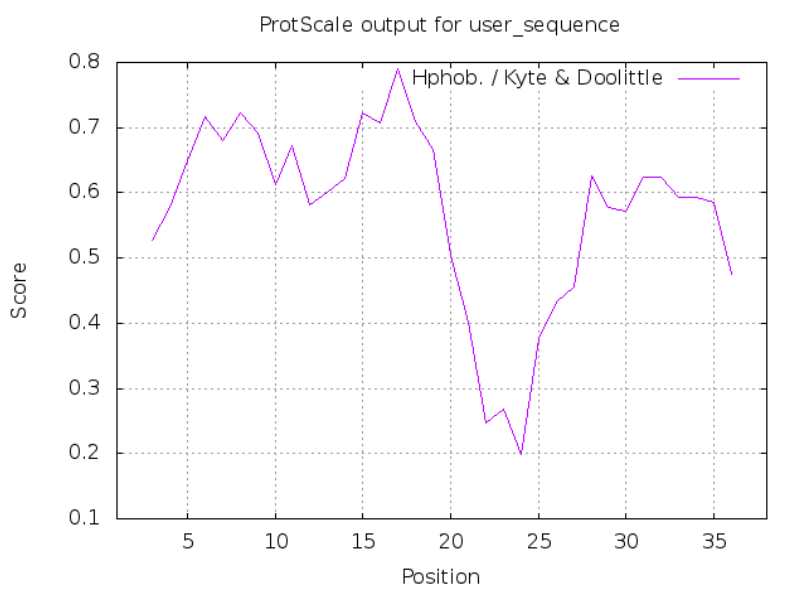

C

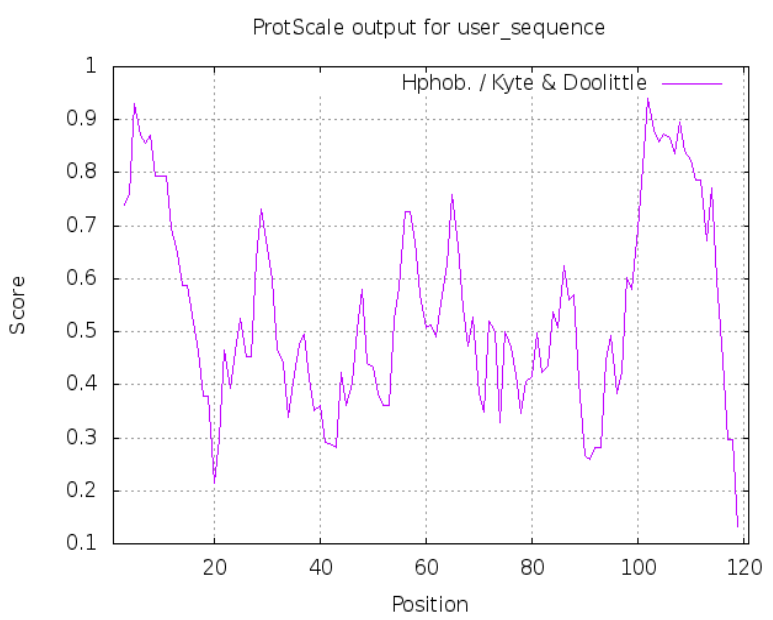

$\mathbf{E}$

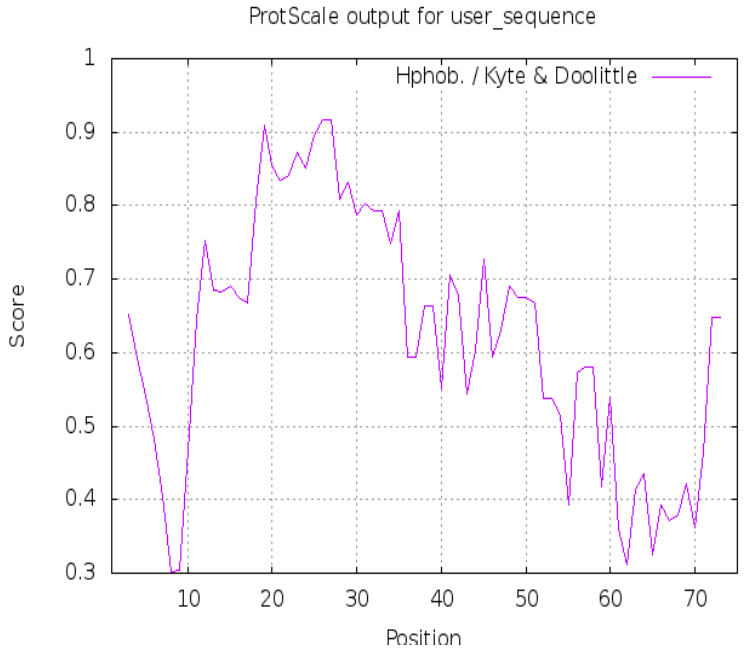

B

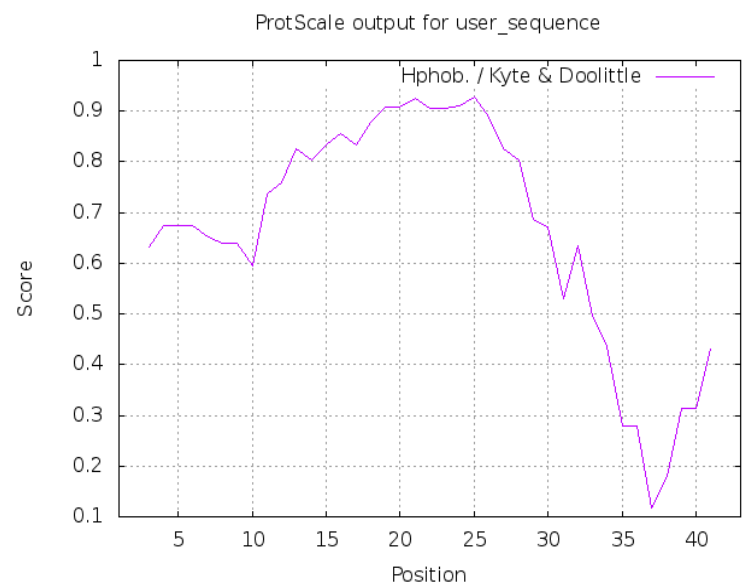

D

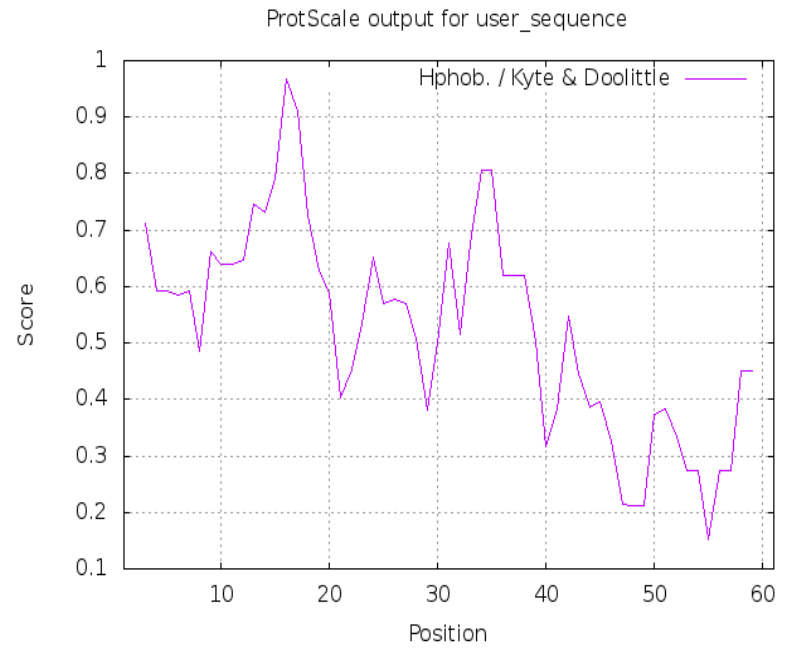

$\mathbf{F}$

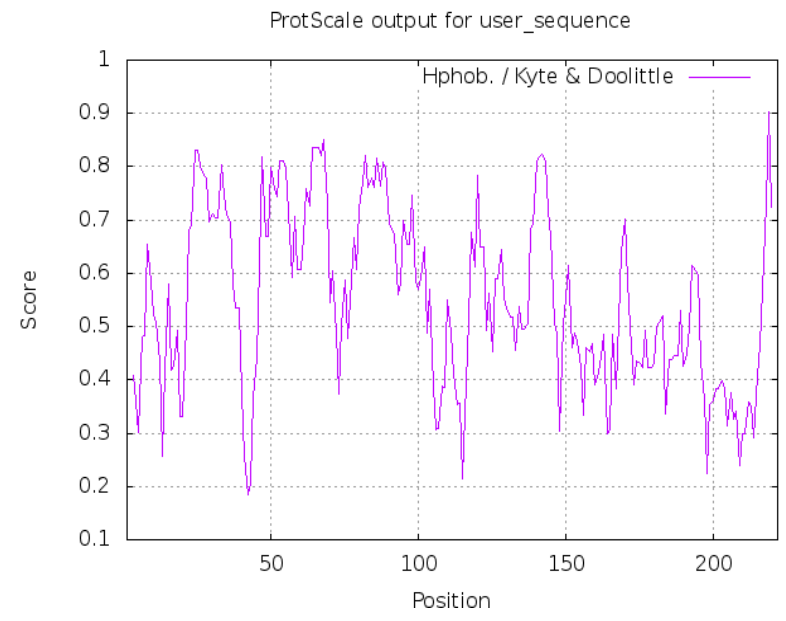




\section{G}

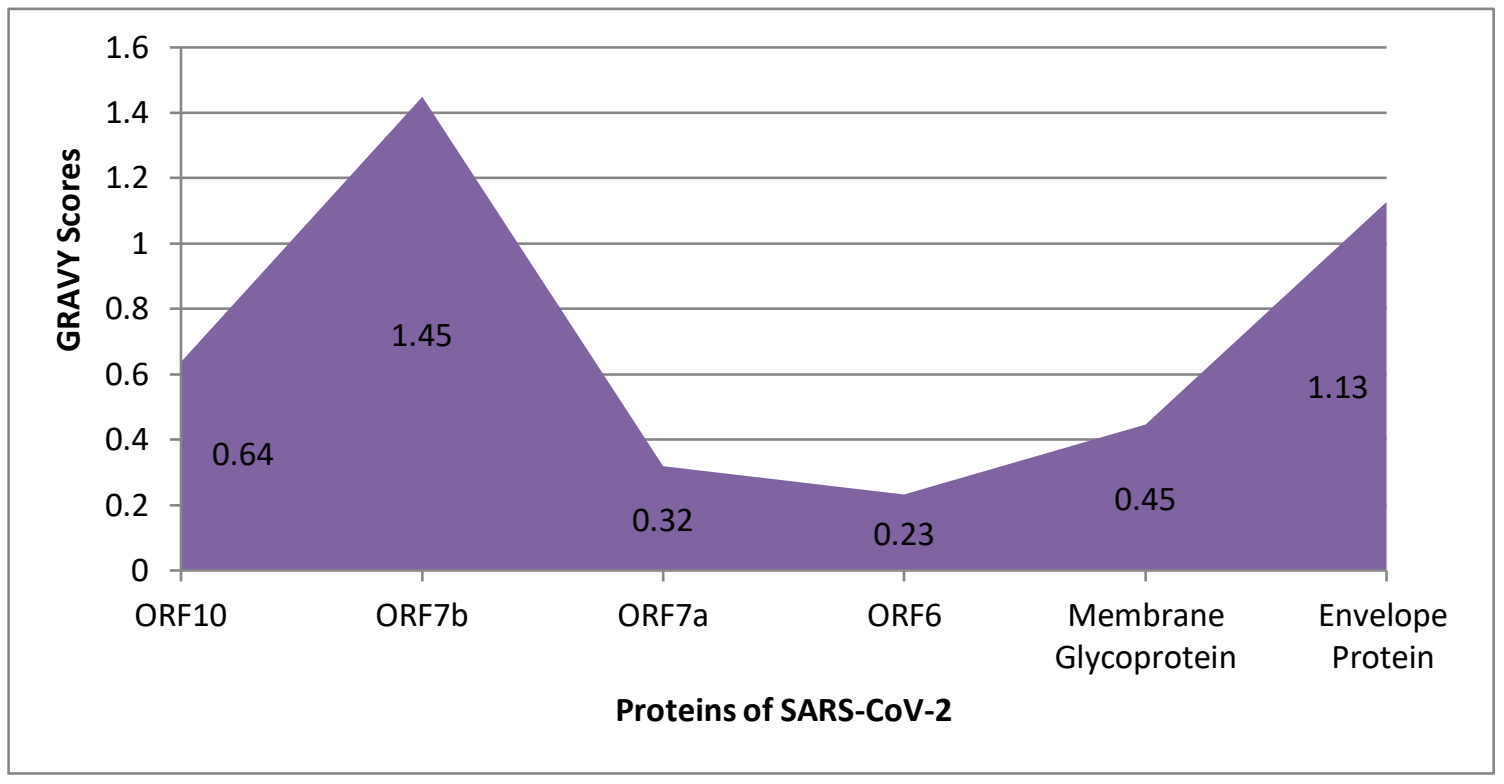

Figure 2. Hydrophobicity plot and GRAVY Scores of selected 6 proteins. 2A-F. Hydrophobicity plot of ORF10, ORF7b, ORF7a and ORF6, membrane glycoprotein, and envelope protein respectively. The hydrophobicity plots were generated according to the Kyte-Doolittle hydropathy plots. 2G. GRAVY Scores of ORF10, ORF7b, ORF7a, ORF6, membrane glycoprotein, and envelope protein. The numerical values for each score displayed above are their corresponding box. The proteins are recognized as mostly hydrophobic.

\subsection{Protein Disorder}

The protein disorder plot indicated that the disorder scores were higher for C-terminal half than $\mathrm{N}$ terminal half for almost all selected proteins (Figure 3). Almost all proteins showed protein disorder scores indicating moderate flexible to highly flexible residues. However, membrane glycoprotein is more disordered compared to other proteins. Also, no protein revealed scores of $\leq 0.1$ indicating rigidity. 


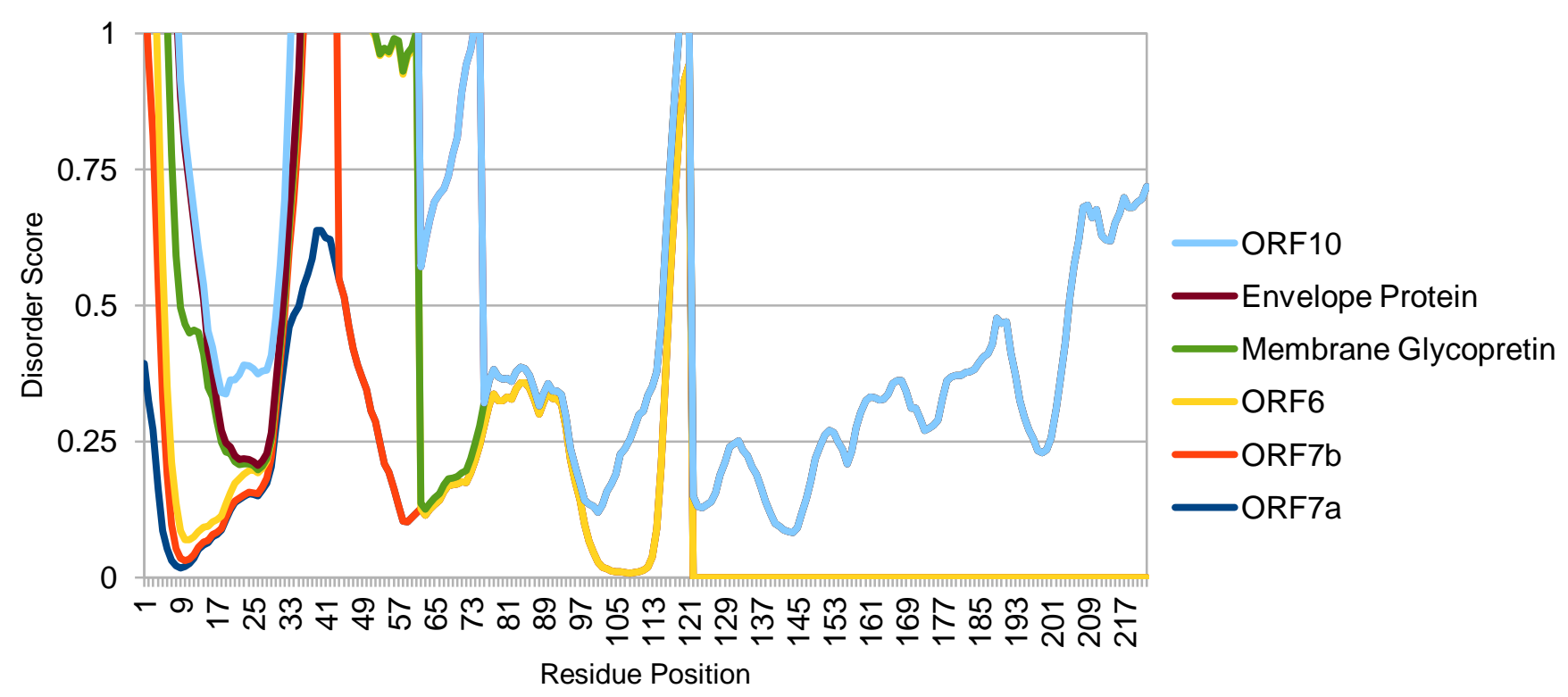

Figure 3. Per-residue disorder plot for ORF10, ORF7b, ORF7a, ORF6, membrane glycoprotein, and envelope protein of SARS-CoV2. All proteins found as highly flexible and ordered. Scores $\geq 0.5$ indicate disorder residues, while scores within 0.25-0.5 and 0.1-0.25 suggest highly flexible and moderate flexible residues. Scores $\leq 0.1$ indicate rigidity.

\subsection{Amino Acids Composition and Protein-Binding Propensity}

The ORF10 protein consists of the highest percentage of asparagines (N), where, in case of ORF7b, ORF7a, membrane glycoprotein, and envelope protein, leucine $(\mathrm{L})$ is presented in the maximum percentage. Moreover, for ORF6, it was isoleucine (Ile). The overall amino acid composition of all 6 proteins has been represented in Table 2. The binding propensity is important to influence electrostatic and aromatic interactions and also it is extremely varied with the amino acid residues. Several fluctuations have been observed in protein-binding propensity in both $\mathrm{C}$-terminal half residues and $\mathrm{N}$ terminal half residues (Supplementary Figure 1). 
Table 2. Amino Acid composition of ORF10, ORF7b, ORF7a, ORF6, membrane glycoprotein, and envelope protein in percentage $(\%)$

\begin{tabular}{|c|c|c|c|c|c|c|}
\hline Amino Acid & ORF10 & ORF7b & ORF7a & ORF6 & $\begin{array}{c}\text { Membrane } \\
\text { Glycoprotein }\end{array}$ & $\begin{array}{l}\text { Envelop } \\
\text { Protein }\end{array}$ \\
\hline Ala (A) & $5.3 \%$ & $4.7 \%$ & $7.4 \%$ & $1.6 \%$ & $8.6 \%$ & $5.3 \%$ \\
\hline $\operatorname{Arg}(\mathrm{R})$ & $5.3 \%$ & $0.0 \%$ & $4.1 \%$ & $1.6 \%$ & $6.3 \%$ & $4.0 \%$ \\
\hline $\operatorname{Asn}(\mathrm{N})$ & $13.2 \%$ & $2.3 \%$ & $1.7 \%$ & $6.6 \%$ & $5.0 \%$ & $6.7 \%$ \\
\hline Asp (D) & $2.6 \%$ & $4.7 \%$ & $1.7 \%$ & $6.6 \%$ & $2.7 \%$ & $1.3 \%$ \\
\hline Cys (C) & $2.6 \%$ & $4.7 \%$ & $5.0 \%$ & $0.0 \%$ & $1.8 \%$ & $4.0 \%$ \\
\hline Gln $(\mathrm{Q})$ & $2.6 \%$ & $2.3 \%$ & $4.1 \%$ & $4.9 \%$ & $1.8 \%$ & $0.0 \%$ \\
\hline Glu (E) & $0.0 \%$ & $7.0 \%$ & $6.6 \%$ & $8.2 \%$ & $3.2 \%$ & $2.7 \%$ \\
\hline Gly $(\mathrm{G})$ & $2.6 \%$ & $0.0 \%$ & $3.3 \%$ & $0.0 \%$ & $6.3 \%$ & $1.3 \%$ \\
\hline His $(\mathrm{H})$ & $0.0 \%$ & $4.7 \%$ & $2.5 \%$ & $1.6 \%$ & $2.3 \%$ & $0.0 \%$ \\
\hline Ile (I) & $7.9 \%$ & $11.6 \%$ & $6.6 \%$ & $16.4 \%$ & $9.0 \%$ & $4.0 \%$ \\
\hline Leu (L) & $10.5 \%$ & $25.6 \%$ & $12.4 \%$ & $13.1 \%$ & $15.8 \%$ & $18.7 \%$ \\
\hline Lys (K) & $0.0 \%$ & $0.0 \%$ & $5.8 \%$ & $6.6 \%$ & $3.2 \%$ & $2.7 \%$ \\
\hline Met (M) & $5.3 \%$ & $4.7 \%$ & $0.8 \%$ & $4.9 \%$ & $1.8 \%$ & $1.3 \%$ \\
\hline Phe (F) & $10.5 \%$ & $14.0 \%$ & $8.3 \%$ & $4.9 \%$ & $5.0 \%$ & $6.7 \%$ \\
\hline Pro (P) & $2.6 \%$ & $0.0 \%$ & $5.0 \%$ & $1.6 \%$ & $2.3 \%$ & $2.7 \%$ \\
\hline Ser $(S)$ & $5.3 \%$ & $4.7 \%$ & $5.8 \%$ & $6.6 \%$ & $6.8 \%$ & $10.7 \%$ \\
\hline Thr (T) & $5.3 \%$ & $2.3 \%$ & $8.3 \%$ & $4.9 \%$ & $5.9 \%$ & $5.3 \%$ \\
\hline $\operatorname{Trp}(\mathrm{W})$ & $0.0 \%$ & $2.3 \%$ & $0.0 \%$ & $1.6 \%$ & $3.2 \%$ & $0.0 \%$ \\
\hline Tyr (Y) & $7.9 \%$ & $2.3 \%$ & $4.1 \%$ & $3.3 \%$ & $4.1 \%$ & $5.3 \%$ \\
\hline Val (V) & $10.5 \%$ & $2.3 \%$ & $6.6 \%$ & $4.9 \%$ & $5.4 \%$ & $17.3 \%$ \\
\hline Pyl (O) & $0.0 \%$ & $0.0 \%$ & $0.0 \%$ & $0.0 \%$ & $0.0 \%$ & $0.0 \%$ \\
\hline $\operatorname{Sec}(\mathrm{U})$ & $0.0 \%$ & $0.0 \%$ & $0.0 \%$ & $0.0 \%$ & $0.0 \%$ & $0.0 \%$ \\
\hline
\end{tabular}

\subsection{Aliphatic Index and Transmembrane Helix}

Aliphatic index values of more than 100 indicated that these proteins are highly thermo-stable over a wide temperature assortment. For ORF10, ORF7b, ORF7a, ORF6, membrane glycoprotein, and envelope protein, the aliphatic index values found were 107.63, 156.51, 100.74, 130.98, 120.86, and144 respectively (Figure 4A). Transmembrane helices of less than one indicated these helices are less likely to interact with membrane lipids. For ORF10 and ORF7a, TH predicted spanning residues are 3-29 and 6-33, respectively. In case of ORF7b, TH predicted residues are 4-23 and 93-119. 
Furthermore, for ORF6 and envelope protein, the predicted TH spanning residues are 5-38 and 11-61. Finally, in case of membrane glycoprotein, the transmembrane helix residues are 18-59 and 61-105. The representation is in Figure 4B.

A

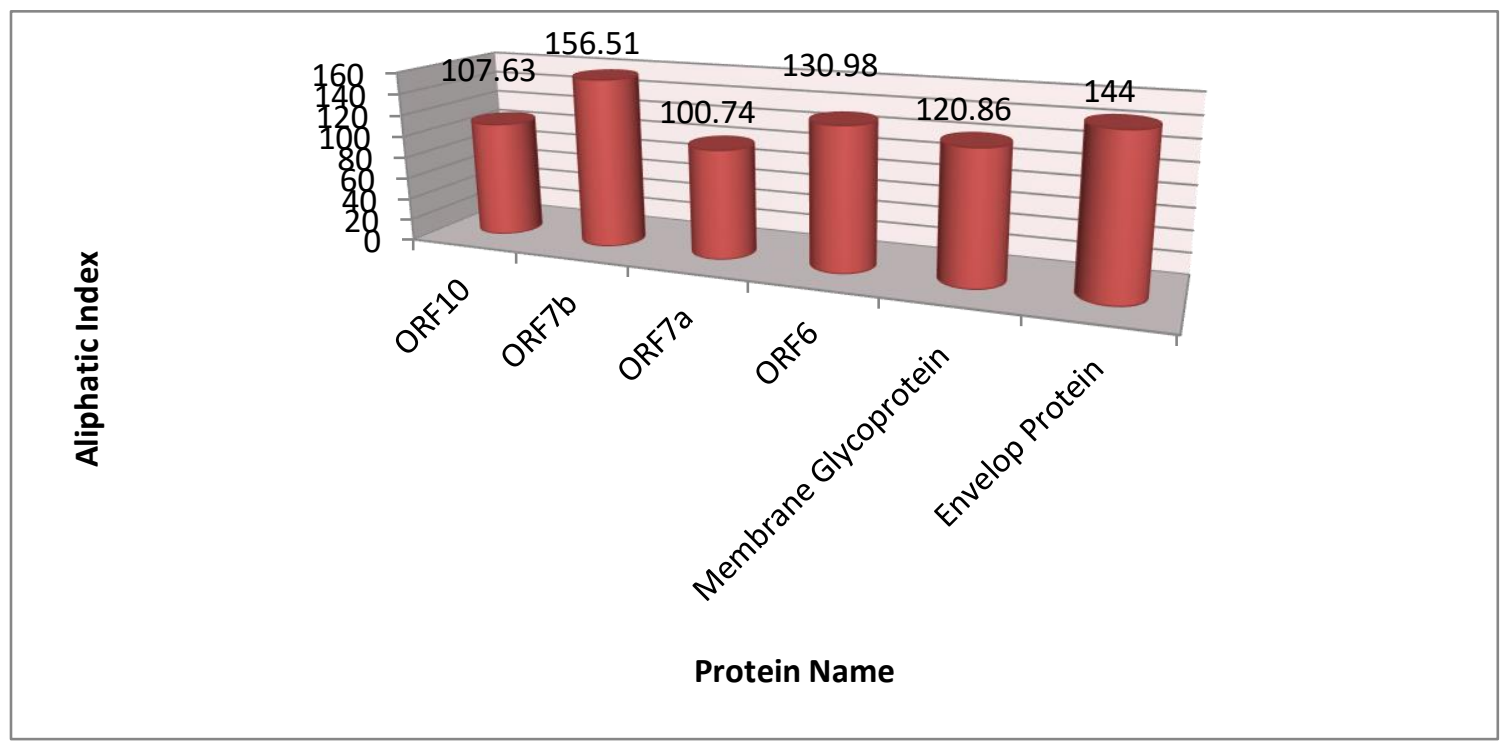

B

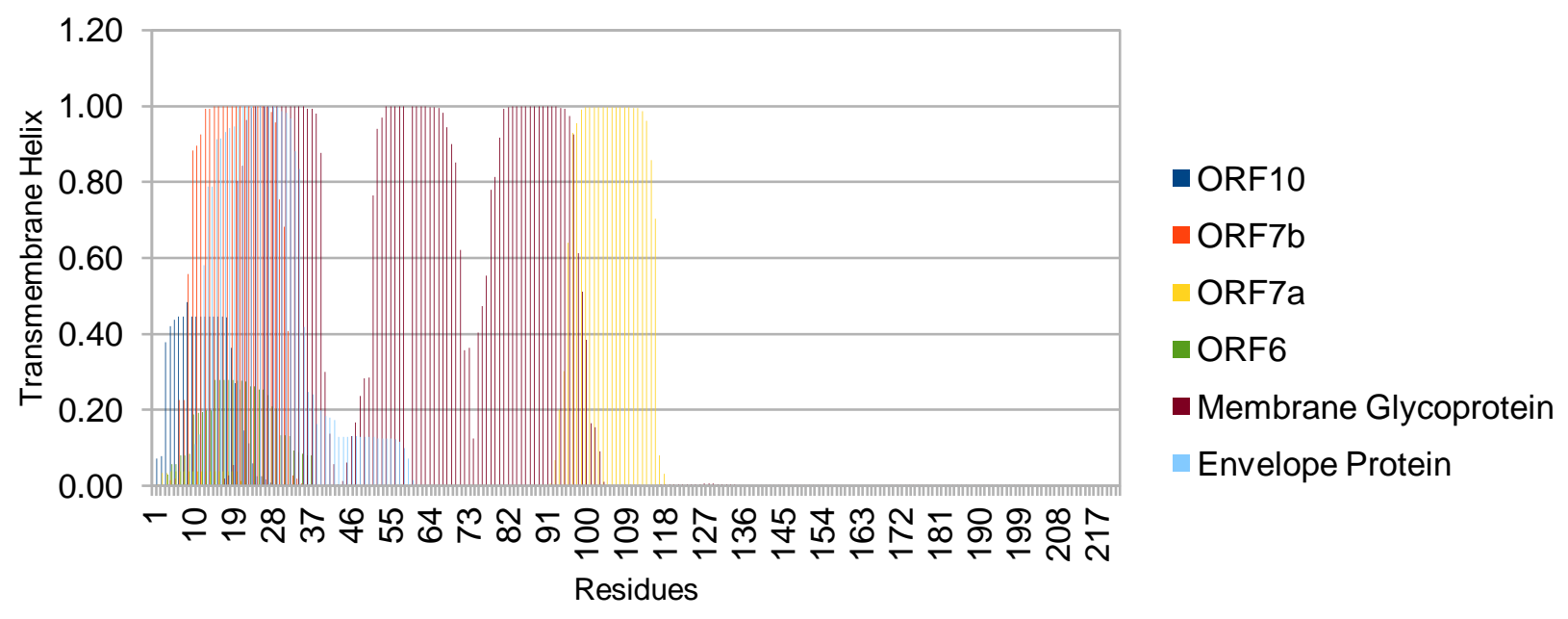

Figure 4. Aliphatic indexes and transmembrane helix prediction scores of ORF10, ORF7b, ORF7a, ORF6, membrane glycoprotein, and envelope protein respectively (4A-B). All proteins showed aliphatic index values of more than 100 indicated that they are highly thermo-stable and transmembrane helices of less than 1 .

\subsection{Protein Secondary Structures}

In respect to ORF10, ORF7b and envelope protein, $\alpha$-helix spanning residues are 11-21, 4-35 and 4-64, respectively (Figure 5A, 5B, 5F). Additionally, in ORF6, the $\alpha$-helix spanning residues are 4-21, 26- 
27, 29-44, 48-51 (Figure 5D). In case of ORF7a, the $\alpha$-helix and $\beta$-sheet spanning residues are 90-96, 99-100 and 28-33, 40-41, 53-66, 72-79, respectively (Figure 5C). The membrane glycoprotein has the $\alpha$-helix and $\beta$-sheet spanning residues of 10-19, 22-36, 40-70, 75-106, 161-163 and 112, 118-123, 128132, 139-146, 148-151, 154-159, 167-172, 175-185, 193-201, respectively (Figure 5E).

A

MGY INVFAFPFT I YSLLLCRMNSRNYIAQVDVVNFNLT

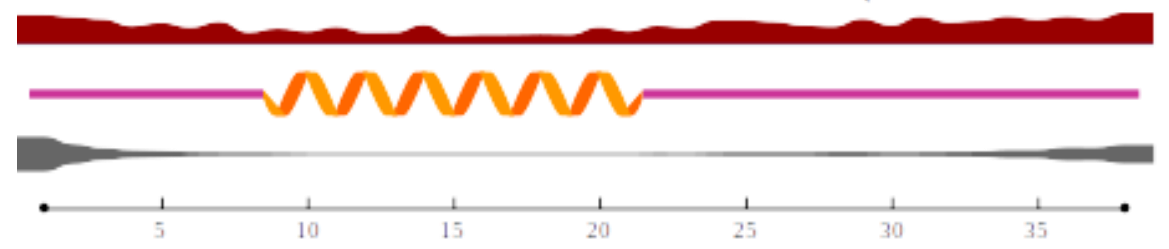

B

MIELSLIDFYLCFLAFLLFLVLIMLI IFWFSLELQDHNETCHA

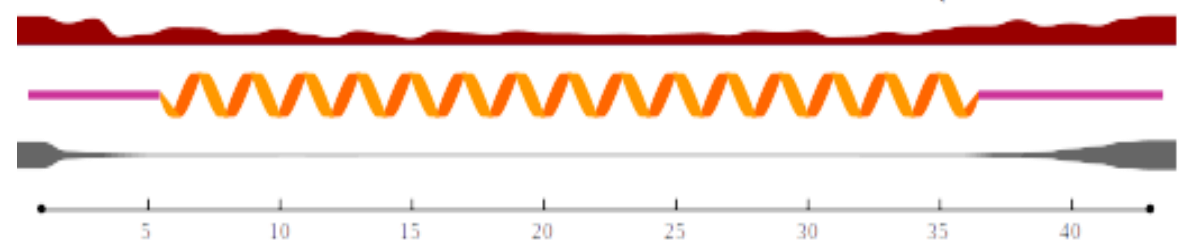

C

MKI ILFLALITLATCELYHYQECVRGTTVLLKEPCSSGTYEGNSPFHPLADNKFALTCFSTQFAFACPDGVKHVYQLRAR

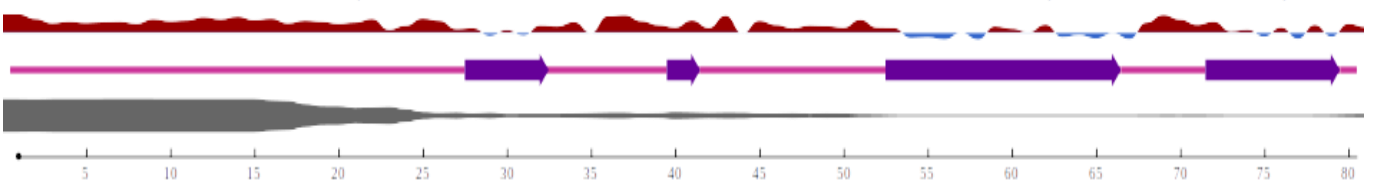

SVSPKLFIRQEEVQELYSPIFLIVAAIVFITLCFTLKRKTE

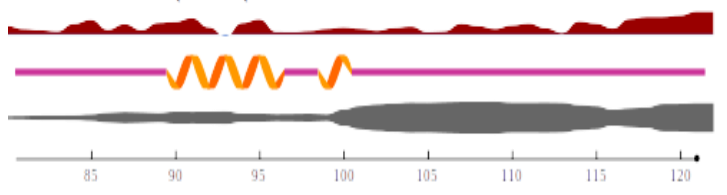

D

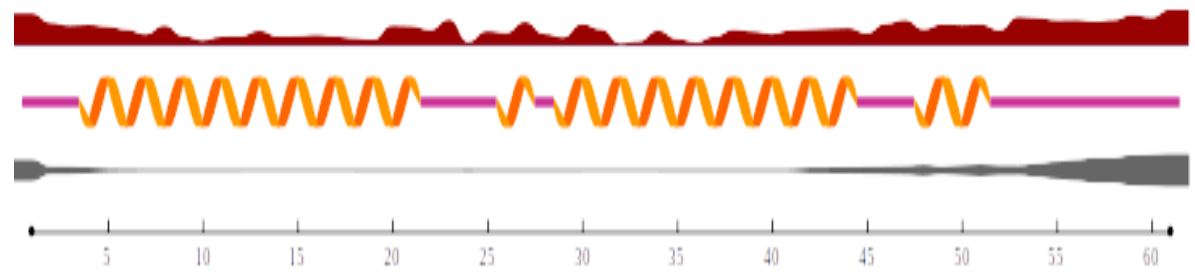


$\mathbf{E}$

MADSNGT I TVEELKKLLEQWNLVIGFLFLTWICLLQFAYANRNRFLYI IKLIFLWLLWPVTLACFVLAAVYRINWITGG I
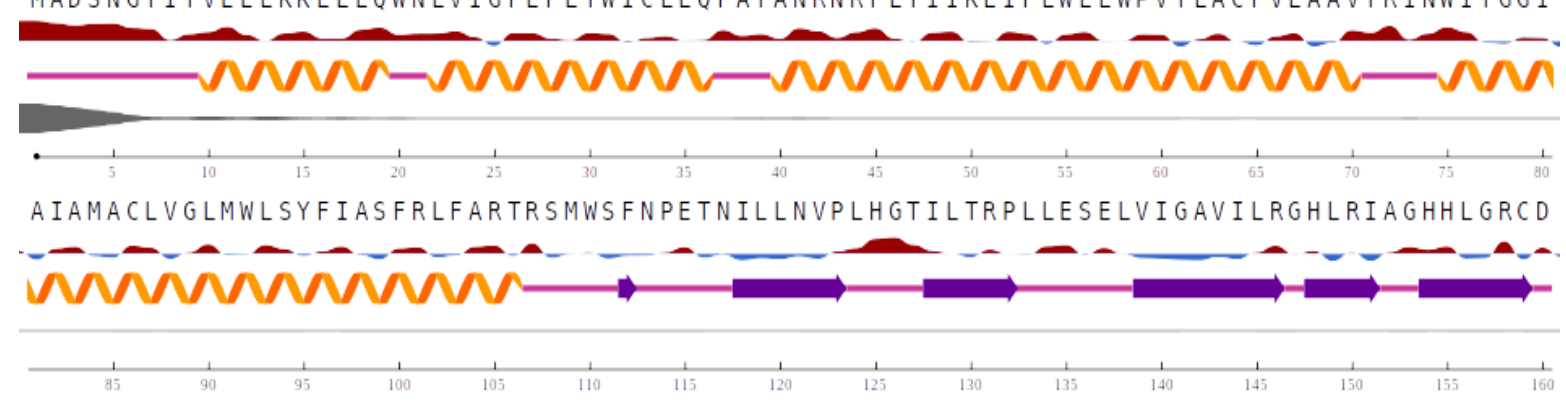

IKDLPKEITVATSRTLSYYKLGASQRVAGDSGFAAYSRYRI GNYKLNTDHSSSSDNIALLVQ
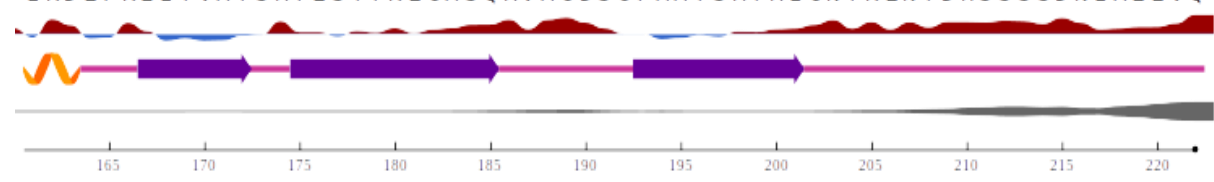

F

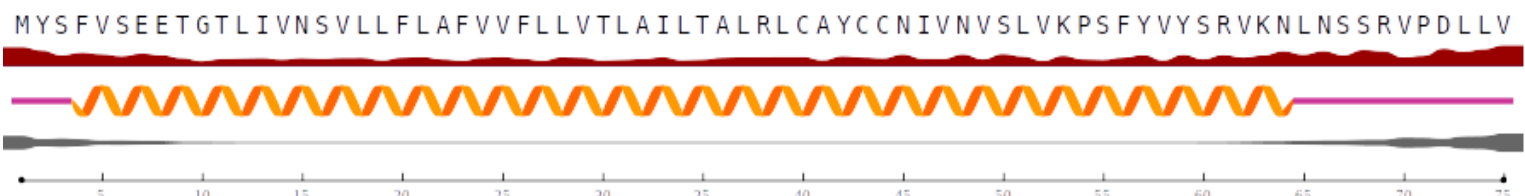

$\mathrm{MW}=$ helix,$\quad=$ coil,$\quad \longrightarrow=$ strand

Figure 5. Secondary structure prediction of 6 selected proteins. 5A-F. Secondary structure of ORF10, ORF7b, ORF7a, ORF6, membrane glycoprotein, and envelope protein respectively.

\subsection{Protein Modeling and Validation}

Initially, the models having low P-values and high-quality scores were subjected to refinement which was yielded by the IntFOLD web-based server. Then the selection was done according to the QMEAN $\mathrm{Z}$ score and Ramachandran plot score (Table S1 and Figure 6A-F). QMEAN Z score and Ramachandran plot score table were added as supplementary table 1 (Table S1). In response to hydrophobic and hydrophilic properties, the majority of the proteins surfaces were found as hydrophobic (Figure 6G-L). The Ramachandran plot score details for all the proteins were found more than $90 \%$ except for membrane glycoprotein which is $87.6 \%$ (Figure 6M-R). 
A

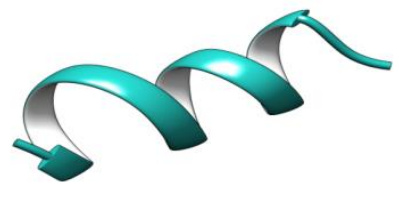

D

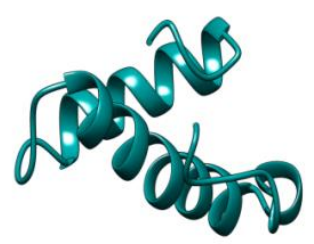

G

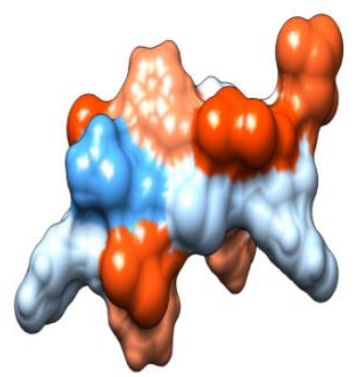

J

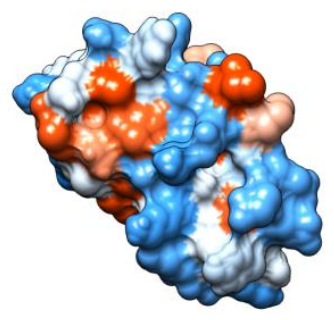

M

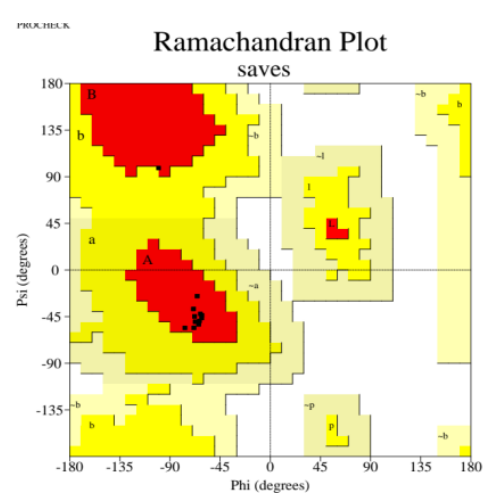

B

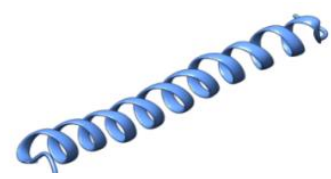

E

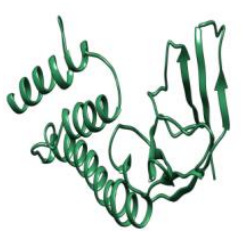

H

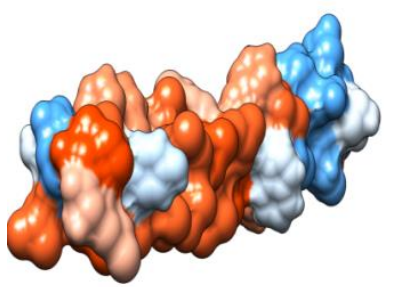

K

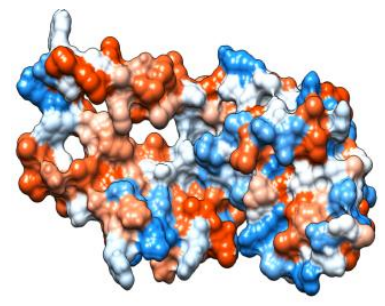

$\mathbf{N}$

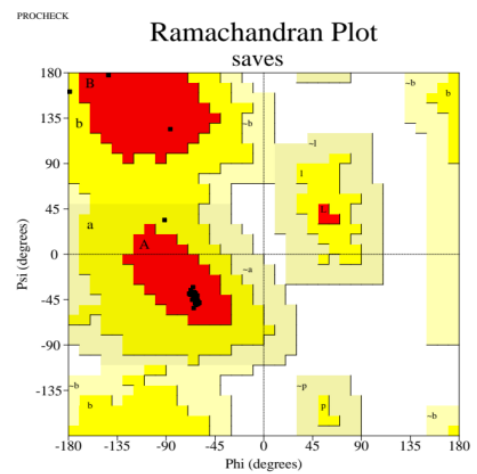

C

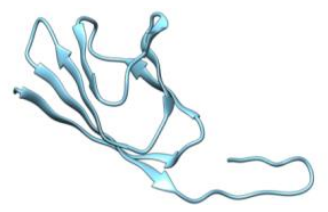

F

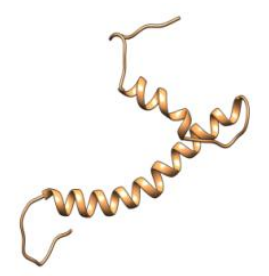

I

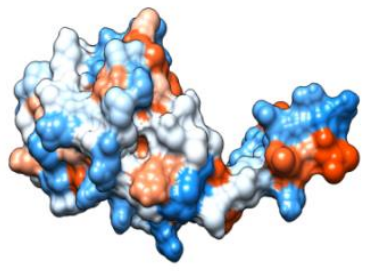

L

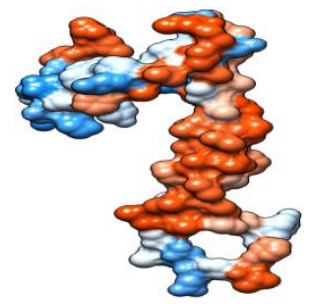

O

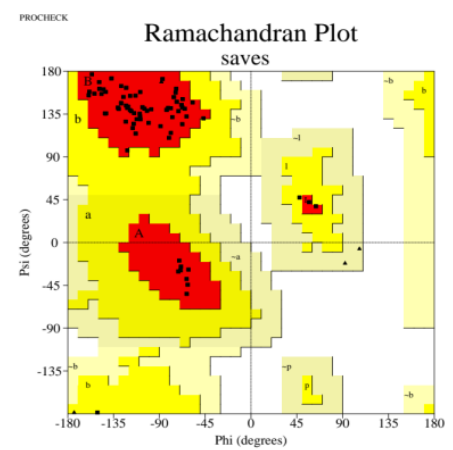



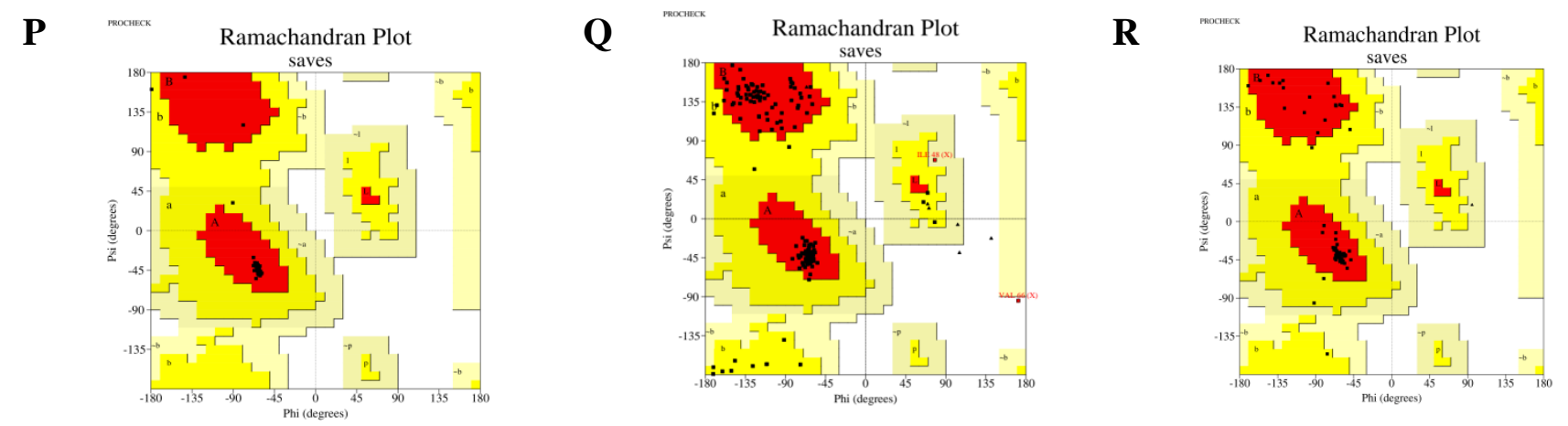

Figure 6. Protein modeling and hydrophobicity surface $3 \mathrm{D}$ map of the selected 6 proteins. 6A-F. Ribbon diagram of ORF10, ORF7b, ORF7a, ORF6, membrane glycoprotein, and envelope protein respectively. 6G-L. Hydrophobicity surface map of ORF10, ORF7b, ORF7a, ORF6, membrane glycoprotein, and envelope protein respectively. All 6 protein models are found as highly flexible and stable. The blue color represents hydrophilic regions and the orange color expresses hydrophobic regions. Where, the whitish-blue color indicates semi-hydrophobic/hydrophilic character. 6M-R. Representation of Ramachandran plots of ORF10, ORF7b, ORF7a, ORF6, membrane glycoprotein, and envelope protein, respectively.

\section{Discussion}

At most, the phylogenetic data in this study proposes the ORF10 protein in Spain is most distantly related to all other ORF10 proteins. Whereas, the high similarity was detected in the other remaining selected ORF10 proteins. While, for ORF7b, ORF7a and ORF6, membrane glycoprotein, envelope protein, there was no distant relationship among the stains from the selected different countries. All these proteins showed $100 \%$ conserved region, thus, mutations in these regions were not created along with revealed that these proteins shared a strong phylogenic relationship with their common ancestors in the past. Conserved regions of ORF7b, ORF7a and ORF6, membrane glycoprotein, and envelope protein could be playing a fundamental role in the assembly of particular proteins, formation of protein structure and/or generating virulent functions by facilitating precise protein interactions. Although, defining relationships between specific sequences is not entirely possible when based solely on sequence data [31]. We can predict that the proteins here are highly ordered as intrinsically disordered proteins have a tendency to be phosphorylated that leads to disorder-to-order along with order-todisorder transitions [32].

Phosphorylation controls the function of the protein and cell signaling by changing conformational shape in the phosphorylated protein which maintains the catalytic property of the particular protein. Thus, activation or inactivation of proteins depends on phosphorylation [33]. Phosphorylation site 
prediction of selected 6 proteins conceded that phosphorylated serine, threonine or tyrosine was mostly not present though ORF7a was showed a single phosphorylated serine. In every conceivable way, the phosphorylation of a distinct protein is able to modify its activities which include inflection of protein's intrinsic biological property, proper sub-cellular location, docking with other related proteins and halflife. It also decides the level and period of a response given by a protein which acts as input to signal integration [34]. Moreover, sites of phosphorylation are more prone to be evolutionary conserved than other interfacial residues [35].

The purpose of the hydropathy index of amino acids is mainly to predict the function of a structurally or functionally unknown protein. The distribution of hydropathy clusters in a particular protein appears to recommend that these cluster location is principally conserved in a given group of proteins [36]. In this present study, selected 6 proteins showed hydropathy index which tended to be more hydrophobic. The literature revealed that hydrophobic proteins are more soluble and for this reason, they can function in an independent manner by avoiding undesirable interactions with watery molecules. In addition to that, these proteins are vital for protein folding which keeps it more stable and biologically active [37].

Protein disorder predictions revealed that almost all proteins showed protein disorder scores indicating moderate flexible to highly flexible residues and no protein revealed scores which indicates rigidity. This result coincides with the result presented by [18]. However, membrane glycoprotein was more disordered compared to other proteins in this study. Protein disorder predictions are an enormous challenge in structural proteomics and subsequently its function prediction including identification of those proteins that are unstructured either partially or wholly. Disordered regions present in specific proteins could contain short linear peptide motifs which may later play a significant role in protein function. After predicting, avoidance of prospective disordered regions in protein can augment expression, proper foldability, and stability of that expressed protein [38].

Protein binding propensity augments the knowledge of protein-protein interactions, docking, and annotation of functional properties of that protein at the molecular level [20]. Also, a high aliphatic index resembles to rise of the thermostability of globuler proteins [39]. All 6 selected proteins showed aliphatic index of more than 100 which indicates these proteins are highly thermo-stable over a wide temperature assortment. In addition, all 6 selected proteins showed transmembrane helixes which are less than 1 and transmembrane helixes have immense importance in the study of membrane proteins [40]. 
Due to the significance of structural class prediction of protein, diverse major efforts have been employed to discover a prediction model that establishes the structural class and predicts protein secondary structure depending on the sequences of protein $[41,42]$. The prediction of secondary structures for six selected proteins revealed that each ORF7a protein and membrane glycoprotein has one $\alpha$-helix and one $\beta$-strand. The structural class is one of the most imperative features for its vital task in the analysis of protein function, prediction of the rate of protein folding nature, and, also, execution of a suitable approach to uncover protein tertiary structure [43]. In this present study, the stable tertiary structure of proteins was predicted which gives the primary notion about the interaction of this protein 3D structures with enzymes or host receptors. Also, in this study, hydrophobicity surface map of particular proteins was created to distinctly show the hydrophobic or hydrophilic regions of protein.

Studying these diverse proteins of the SARS-CoV-2 virus has already yielded some clues about how they connect with the human cells but much remains to be assessed. The present study explored theoretical modeling, sequence and structure-based functional characterization of six accessory proteins. Phylogenetic analysis of these proteins exposed a close evolutionary relationship with the proteins of distant origins. Though further comprehensive assessment with broad-scale data are required to elucidate these upshots generated in this current study.

\section{Conclusion}

Communally, the present study provides an interesting basis for characterizing proteins of novel viruses theoretically and structurally. The selected proteins appear stable, ordered, hydrophobic, and also share strong phylogenetic relationships with proteins of other closely related SARS-CoV-2. Finally, the tertiary models of protein constructed in this study have higher quality and stability. This analysis can offer a foundation to perform the further analysis necessary to evaluate the biological function, interaction, and relevance to viral property of the 6 proteins in SARS-CoV-2. Perhaps, the theoretical structures would be functional for investigation of each protein interaction and their functionalities by advanced computational analysis, understanding of viral pathogenesis or to study potential vaccines and especially, to avert epidemics and pandemics. 


\section{Data availability}

The reference FASTA sequence corresponding to the selected six proteins (ORF10, ORF7b, ORF7a, ORF6, membrane glycoprotein, and envelope protein) SARS-CoV-2 strain G039392 along with other 9 variants of SARS-CoV-2 from 9 different countries were acquired and still available in NCBI's Protein Database (https://www.ncbi.nlm.nih.gov/protein/?term=).

\section{Conflicts of Interest}

All authors declare no conflict of interest.

\section{Funding}

This research received no specific grant from any funding agency in the public, commercial or not-forprofit sectors.

\section{Supplementary material}

A supplementary file is provided along with the main manuscript containing the figures of protein-binding propensity of the selected 6 proteins (Supplementary Figure 1) and also, a table comprising selected QMEAN Z-Scores and Ramachandran Plot Scores for protein modeling (Table S1).

\section{References}

1. Wang C, Horby PW, Hayden FG, Gao GF. A novel coronavirus outbreak of global health concern. Lancet. 2020 Feb 15;395(10223):470-473. doi: 10.1016/S0140-6736(20)30185-9. Epub 2020 Jan 24. Erratum in: Lancet. 2020 Jan 29;: PMID: 31986257; PMCID: PMC7135038.

2. Paules CI, Marston HD, Fauci AS. Coronavirus Infections-More Than Just the Common Cold. JAMA. 2020 Feb 25;323(8):707-708. doi: 10.1001/jama.2020.0757. PMID: 31971553.

3. Sahin AR, Erdogan A, Agaoglu PM, Dineri Y, Cakirci AY, Senel ME, Okyay RA, Tasdogan AM. 2019 novel coronavirus (COVID-19) outbreak: a review of the current literature. EJMO. 2020;4(1):1-7.

4. Shereen MA, Khan S, Kazmi A, Bashir N, Siddique R. COVID-19 infection: Origin, transmission, and characteristics of human coronaviruses. J Adv Res. 2020 Mar 16;24:91-98. doi: 10.1016/j.jare.2020.03.005. PMID: 32257431; PMCID: PMC7113610.

5. Khailany RA, Safdar M, Ozaslan M. Genomic characterization of a novel SARS-CoV-2. Gene Rep. 2020 Jun;19:100682. doi: 10.1016/j.genrep.2020.100682. Epub 2020 Apr 16. PMID: 32300673; PMCID: PMC7161481.

6. Schaecher SR, Mackenzie JM, Pekosz A. The ORF7b protein of severe acute respiratory syndrome coronavirus (SARS-CoV) is expressed in virus-infected cells and incorporated into SARS-CoV particles. J Virol. 2007 Jan;81(2):718-31. doi: 10.1128/JVI.01691-06. Epub 2006 Nov 1. PMID: 17079322; PMCID: PMC1797472. 
7. Lu S, Wang J, Chitsaz F, Derbyshire MK, Geer RC, Gonzales NR, Gwadz M, Hurwitz DI, Marchler GH, Song JS, Thanki N, Yamashita RA, Yang M, Zhang D, Zheng C, Lanczycki CJ, Marchler-Bauer A. CDD/SPARCLE: the conserved domain database in 2020. Nucleic Acids Res. 2020 Jan 8;48(D1):D265D268. doi: 10.1093/nar/gkz991. PMID: 31777944; PMCID: PMC6943070.

8. Geng H, Liu YM, Chan WS, Lo AW, Au DM, Waye MM, Ho YY. The putative protein 6 of the severe acute respiratory syndrome-associated coronavirus: expression and functional characterization. FEBS Lett. 2005 Dec 19;579(30):6763-8. doi: 10.1016/j.febslet.2005.11.007. Epub 2005 Nov 21. PMID: 16310783; PMCID: PMC7094358.

9. Wu F, Zhao S, Yu B, Chen YM, Wang W, Song ZG, Hu Y, Tao ZW, Tian JH, Pei YY, Yuan ML, Zhang YL, Dai FH, Liu Y, Wang QM, Zheng JJ, Xu L, Holmes EC, Zhang YZ. A new coronavirus associated with human respiratory disease in China. Nature. 2020 Mar;579(7798):265-269. doi: 10.1038/s41586-020-2008-3. Epub 2020 Feb 3. Erratum in: Nature. 2020 Apr;580(7803):E7. PMID: 32015508; PMCID: PMC7094943.

10. de Haan CA, Smeets M, Vernooij F, Vennema H, Rottier PJ. Mapping of the coronavirus membrane protein domains involved in interaction with the spike protein. J Virol. 1999 Sep;73(9):7441-52. doi: 10.1128/JVI.73.9.7441-7452.1999. PMID: 10438834; PMCID: PMC104271.

11. Surya W, Li Y, Torres J. Structural model of the SARS coronavirus E channel in LMPG micelles. Biochim Biophys Acta Biomembr. 2018 Jun;1860(6):1309-1317. doi: 10.1016/j.bbamem.2018.02.017. Epub 2018 Feb 21. PMID: 29474890; PMCID: PMC7094280.

12. Hossain ME, Rahman MM, Alam MS, Karim Y, Hoque AF, Rahman S, Rahman MZ, Rahman M. Genome Sequence of a SARS-CoV-2 Strain from Bangladesh That Is Nearly Identical to United Kingdom SARSCoV-2 Variant B.1.1.7. Microbiol Resour Announc. 2021 Feb 25;10(8):e00100-21. doi: 10.1128/MRA.00100-21. PMID: 33632858; PMCID: PMC7909083.

13. Edgar RC. MUSCLE: multiple sequence alignment with high accuracy and high throughput. Nucleic Acids Res. 2004 Mar 19;32(5):1792-7. doi: 10.1093/nar/gkh340. PMID: 15034147; PMCID: PMC390337.

14. Kumar S, Stecher G, Li M, Knyaz C, Tamura K. MEGA X: Molecular Evolutionary Genetics Analysis across Computing Platforms. Mol Biol Evol. 2018 Jun 1;35(6):1547-1549. doi: 10.1093/molbev/msy096. PMID: 29722887; PMCID: PMC5967553.

15. Boris Igic, Phylogenetic Trees Made Easy: A How-To Manual, 2nd ed., Journal of Heredity, Volume 96, Issue 4, July/August 2005, Pages 469-470, https://doi.org/10.1093/jhered/esi046

16. Xue B, Dunbrack RL, Williams RW, Dunker AK, Uversky VN. PONDR-FIT: a meta-predictor of intrinsically disordered amino acids. Biochimica et Biophysica Acta (BBA)-Proteins and Proteomics. 2010 Apr 1;1804(4):996-1010. https://doi.org/10.1016/j.bbapap.2010.01.011

17. Gasteiger E, Hoogland C, Gattiker A, Wilkins MR, Appel RD, Bairoch A. Protein identification and analysis tools on the ExPASy server. The proteomics protocols handbook. 2005:571-607. DOI: 10.1385/1-59259890-0:571

18. Simm S, Einloft J, Mirus O, Schleiff E. 50 years of amino acid hydrophobicity scales: revisiting the capacity for peptide classification. Biol Res. 2016 Jul 4;49(1):31. doi: 10.1186/s40659-016-0092-5. PMID: 27378087; PMCID: PMC4932767.

19. Giri R, Bhardwaj T, Shegane M, Gehi BR, Kumar P, Gadhave K, Oldfield CJ, Uversky VN. Understanding COVID-19 via comparative analysis of dark proteomes of SARS-CoV-2, human SARS and bat SARS-like coronaviruses. Cell Mol Life Sci. 2021 Feb;78(4):1655-1688. doi: 10.1007/s00018-020-03603-x. Epub 2020 Jul 25. PMID: 32712910; PMCID: PMC7382329. 
20. Zhang J, Kurgan L. SCRIBER: accurate and partner type-specific prediction of protein-binding residues from proteins sequences. Bioinformatics. 2019 Jul 15;35(14):i343-i353. doi: 10.1093/bioinformatics/btz324. PMID: 31510679; PMCID: PMC6612887.

21. Klausen MS, Jespersen MC, Nielsen H, Jensen KK, Jurtz VI, Sønderby CK, Sommer MOA, Winther O, Nielsen M, Petersen B, Marcatili P. NetSurfP-2.0: Improved prediction of protein structural features by integrated deep learning. Proteins. 2019 Jun;87(6):520-527. doi: 10.1002/prot.25674. Epub 2019 Mar 9. PMID: 30785653.

22. Krogh A, Larsson B, von Heijne G, Sonnhammer EL. Predicting transmembrane protein topology with a hidden Markov model: application to complete genomes. J Mol Biol. 2001 Jan 19;305(3):567-80. doi: 10.1006/jmbi.2000.4315. PMID: 11152613.

23. Käll L, Krogh A, Sonnhammer EL. A combined transmembrane topology and signal peptide prediction method. J Mol Biol. 2004 May 14;338(5):1027-36. doi: 10.1016/j.jmb.2004.03.016. PMID: 15111065.

24. McGuffin LJ, Adiyaman R, Maghrabi AHA, Shuid AN, Brackenridge DA, Nealon JO, Philomina LS. IntFOLD: an integrated web resource for high performance protein structure and function prediction. Nucleic Acids Res. 2019 Jul 2;47(W1):W408-W413. doi: 10.1093/nar/gkz322. PMID: 31045208; PMCID: PMC6602432.

25. Bhattacharya D, Cheng J. 3Drefine: consistent protein structure refinement by optimizing hydrogen bonding network and atomic-level energy minimization. Proteins. 2013 Jan;81(1):119-31. doi: 10.1002/prot.24167. Epub 2012 Sep 26. PMID: 22927229; PMCID: PMC3634918.

26. Benkert P, Biasini M, Schwede T. Toward the estimation of the absolute quality of individual protein structure models. Bioinformatics. 2011 Feb 1;27(3):343-50. doi: 10.1093/bioinformatics/btq662. Epub 2010 Dec 5. PMID: 21134891; PMCID: PMC3031035.

27. Hollingsworth SA, Karplus PA. A fresh look at the Ramachandran plot and the occurrence of standard structures in proteins. Biomol Concepts. 2010 Oct;1(3-4):271-283. doi: 10.1515/BMC.2010.022. PMID: 21436958; PMCID: PMC3061398.

28. Pettersen EF, Goddard TD, Huang CC, Couch GS, Greenblatt DM, Meng EC, Ferrin TE. UCSF Chimera--a visualization system for exploratory research and analysis. J Comput Chem. 2004 Oct;25(13):1605-12. doi: 10.1002/jcc.20084. PMID: 15264254.

29. Lineback JE, Jansma AL. PyMOL as an instructional tool to represent and manipulate the myoglobin/hemoglobin protein system. Journal of Chemical Education. 2019 Oct 31;96(11):2540-4. https://doi.org/10.1021/acs.jchemed.9b00143

30. Kyte J, Doolittle RF. A simple method for displaying the hydropathic character of a protein. J Mol Biol. 1982 May 5;157(1):105-32. doi: 10.1016/0022-2836(82)90515-0. PMID: 7108955.

31. Schuster NA. Characterization and structural prediction of the putative ORF10 protein in SARS-CoV-2. bioRxiv. 2021 Jan 1:2020-10. doi: https://doi.org/10.1101/2020.10.26.355784.

32. Collins MO, Yu L, Campuzano I, Grant SG, Choudhary JS. Phosphoproteomic analysis of the mouse brain cytosol reveals a predominance of protein phosphorylation in regions of intrinsic sequence disorder. Mol Cell Proteomics. 2008 Jul;7(7):1331-48. doi: 10.1074/mcp.M700564-MCP200. Epub 2008 Apr 3. PMID: 18388127. 
33. Stolarczyk EI, Reiling CJ, Paumi CM. Regulation of ABC transporter function via phosphorylation by protein kinases. Curr Pharm Biotechnol. 2011 Apr;12(4):621-35. doi: 10.2174/138920111795164075. PMID: 21118091 ; PMCID: PMC3085954.

34. Cohen $P$. The regulation of protein function by multisite phosphorylation--a 25 year update. Trends Biochem Sci. 2000 Dec; 25(12):596-601. doi: 10.1016/s0968-0004(00)01712-6. PMID: 11116185.

35. Nishi H, Hashimoto K, Panchenko AR. Phosphorylation in protein-protein binding: effect on stability and function. Structure. 2011 Dec 7;19(12):1807-15. doi: 10.1016/j.str.2011.09.021. PMID: 22153503; PMCID: PMC3240861.

36. Damodharan L, Pattabhi V. Hydropathy analysis to correlate structure and function of proteins. Biochem Biophys Res Commun. 2004 Oct 22;323(3):996-1002. doi: 10.1016/j.bbrc.2004.08.186. PMID: 15381098.

37. Tsai CJ, Lin SL, Wolfson HJ, Nussinov R. Studies of protein-protein interfaces: a statistical analysis of the hydrophobic effect. Protein Sci. 1997 Jan;6(1):53-64. doi: 10.1002/pro.5560060106. PMID: 9007976; PMCID: PMC2143524.

38. Linding R, Jensen LJ, Diella F, Bork P, Gibson TJ, Russell RB. Protein disorder prediction: implications for structural proteomics. Structure. 2003 Nov;11(11):1453-9. doi: 10.1016/j.str.2003.10.002. PMID: 14604535.

39. Ikai A. Thermostability and aliphatic index of globular proteins. J Biochem. 1980 Dec;88(6):1895-8. PMID: 7462208.

40. Cuthbertson JM, Doyle DA, Sansom MS. Transmembrane helix prediction: a comparative evaluation and analysis. Protein Eng Des Sel. 2005 Jun;18(6):295-308. doi: 10.1093/protein/gzi032. Epub 2005 Jun 2. PMID: 15932905.

41. Chen C, Tian YX, Zou XY, Cai PX, Mo JY. Using pseudo-amino acid composition and support vector machine to predict protein structural class. J Theor Biol. 2006 Dec 7;243(3):444-8. doi: 10.1016/j.jtbi.2006.06.025. Epub 2006 Jul 1. PMID: 16908032.

42. Zhang TL, Ding YS, Chou KC. Prediction protein structural classes with pseudo-amino acid composition: approximate entropy and hydrophobicity pattern. J Theor Biol. 2008 Jan 7;250(1):186-93. doi: 10.1016/j.jtbi.2007.09.014. Epub 2007 Sep 15. PMID: 17959199.

43. Dai Q, Li Y, Liu X, Yao Y, Cao Y, He P. Comparison study on statistical features of predicted secondary structures for protein structural class prediction: From content to position. BMC Bioinformatics. 2013 May 4;14:152. doi: 10.1186/1471-2105-14-152. PMID: 23641706; PMCID: PMC3652764. 